The American Journal of Applied sciences

(ISSN - 2689-0992)

VOLUME 04 ISSUE 01 Pages: 4-11

SJIF IMPACT FACTOR (2020: 5. 276) (2021: 5. 634)

OCLC - 1121105553 METADATA IF - 7.987

Crossref dol gi Google

Research Article

\title{
TEACHING MOLECULAR PHYSICS WITH PROBLEM SOLVING
}

Submission Date: January 10, 2021, Accepted Date: January 20, 2022,
Published Date: January 30, 2022 |
Crossref doi: https://doi.org/10.37547/tajas/Volume04Issue01-02

Journal Website: https://theamericanjou rnals.com/index.php/ta jas

Copyright: Original content from this work may be used under the terms of the creative commons attributes 4.0 licence.

\section{ABSTRACT}

Ilmiral Idarovna Absalyamova

Assistant Teacher of Tashkent University of Information Technologies named after Muhammad alKhorezmiy, Uzbekistan

\section{Ozoda Odilovna Ochilova}

PhD of Technical Sciences, Associate Professor of Tashkent University of Information Technologies named after Muhammad al-Khorezmiy, Uzbekistan

\section{Almagul Kurbanbekovna Ashirbayeva}

Assistant Teacher of Tashkent University of Information Technologies named after Muhammad alKhorezmiy, Uzbekistan

Mohira Fayzullaevna Rahmatullaeva PhD of Physical and Mathematical Sciences, Associate Professor of Tashkent University of Information Technologies named after Muhammad al-Khorezmiy, Uzbekistan

Shoira Isajanovna Abdullaeva, Assistant Teacher Associate Professor of Tashkent University of Information Technologies named after Muhammad al-Khorezmiy, Uzbekistan

This article provides with some of the tasks and goals of molecular physics as a subject and shows several examples of problems solved in molecular physics, and methods for solving them. Here are some ways to solve each problem in several ways.

\section{KEYWORDS}

Pedagogical work, molecular physics, problems, system of continuous education, educational process, educational activity, set of requirements. 
The American Journal of Applied sciences

(ISSN - 2689-0992)

VOLUME 04 ISSUE 01 Pages: 4-11

SJIF IMPACT FACTOR (2020: 5. 276) (2021: 5. 634)

OCLC - 1121105553 METADATA IF - 7.987

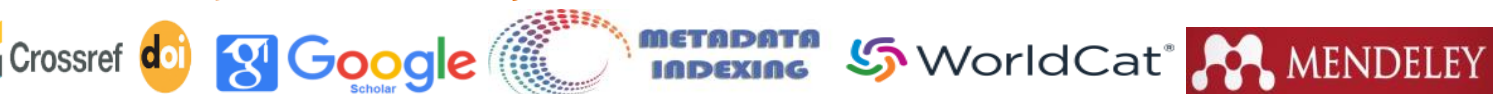

Publisher: The USA Journals

\section{INTRODUCTION}

Molecular physics is a branch of physics that studies the structure and properties of matter based on the socalled molecular-kinetic concepts. The molecularkinetic theory aims to interpret those properties of bodies that are directly observed in experience as the total result of the action of molecules. At the same time, she uses the statistical method, being interested not in the movement of individual molecules, but only in such average values that characterize the movement of a huge collection of particles. Hence its other name - statistical physics.

\section{MATERIALS AND METHODS}

In contrast to the molecular-kinetic theory, thermodynamics studies the macroscopic properties of bodies and natural phenomena without being interested in their macroscopic picture. In this section, the goal was to reveal to students the methods of scientific knowledge of physical phenomena in the framework of studying the foundations of thermodynamics and molecular physics.

When presenting transport phenomena, surface phenomena, phase transitions and some issues of gas dynamics, this section reflects the works of the authors published in the press.

The second law of thermodynamics is presented in two parts - separately for reversible and irreversible processes. The Boltzmann distribution is taken as the basis for the formation of molecular-kinetic representations under the conditions of applicability of classical statistics. This distribution is used to describe interacting particles.

Combining the methods of statistical physics and thermodynamics makes it possible to study both the structure of matter and the processes occurring in gases, liquids and solids.

The selected topics in teaching this subject cover all the basic laws of molecular physics and thermodynamics. They set out the scientific foundations of the course, which are necessary for understanding and explaining physical phenomena and laws, their use in science and technology.

Without knowledge of the basic laws and phenomena related to the course, one cannot begin to study applied and special courses. To this end, the molecular physics course has chosen topics that will help improve the educational process in the future and will be useful in studying other courses in physics.

To do this, students must have the following skills in the course "Molecular Physics":

- Using the laws of an ideal gas and the equation of state of an ideal gas, they must be able to determine the parameters of a particular state of the gas;

- Calculate the number or proportion of moving molecules in a certain speed interval;

- Calculate in various processes the change in the internal energy of the gas, the work done by the gas, the amount of heat received or given away, corresponding to the heat capacities of gases;

- Know the cause of the occurrence of transport phenomena in gases and liquids, know the meaning of the transport coefficients, calculate the mean free path and the value of the transport coefficients;

- Master the basic laws of thermodynamics, the principle of operation of cyclic machines and the 
The American Journal of Applied sciences

(ISSN - 2689-0992)

VOLUME 04 ISSUE 01 Pages: 4-11

SJIF IMPACT FACTOR (2020: 5. 276) (2021: 5. 634)

OCLC - 1121105553 METADATA IF -7.987

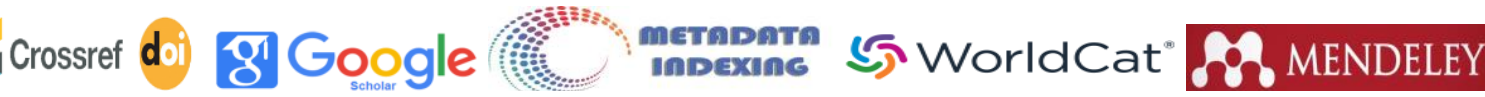

Before studying ready-made solutions to problems in molecular physics, you need to know the theory, so for you I have prepared a brief theory in the section "molecular physics", and examples of solutions in which problems are solved in detail. conditions for obtaining maximum useful work in them;

- Know the cause of the difference between the states of ideal and real gases. Based on the acquired knowledge, determine the parameters of the state of a real gas;

- Know the causes of the surface tension force on the surface of the liquid and the appearance of the capillary phenomenon.

Problem 1. Atmospheric pressure at the peak of the tower (height $7134 \mathrm{~m}$ ) $p_{1}=3,8 \cdot 10^{4}$ Пa . Determine air density $\rho_{1}$ at the top at temperature $t_{1}=-10^{\circ} \mathrm{C}$, if under normal conditions $\left(t_{0}=0^{\circ} \mathrm{C}, p_{0}=10^{5} \Pi \mathrm{a}\right)$, air density $\rho_{0}=1,29 \mathrm{K \Gamma} / \mathrm{M}^{3}$.

Solution :

The equation of state for an ideal gas (Clapeyron-Mendeleev equation) can be written in the following form:

$$
\rho=\frac{p M}{R T} \text {, where } \rho=m / V_{\text {_air density, }} \rho \text { _pressure, } M_{\text {_molar mass, }} T_{\text {- absolute gas temperature }}
$$$$
\rho_{0}=\frac{p_{0} M}{R T_{0}}, \quad \rho_{1}=\frac{p_{1} M}{R T_{1}}, \text { where } T_{0}=t_{0}+273^{\circ} \mathrm{C}, T_{1}=t_{1}+273^{\circ} \mathrm{C}, \text { we get the answer: }
$$$$
\rho_{1}=\rho_{0} \frac{p_{1} T_{0}}{p_{0} T_{1}}=0,51 \mathrm{\kappa г} / \mathrm{m}^{3} .
$$

Problem 2. Find the ratio $k$ of the maximum density of an ideal gas to its minimum density, which are achieved in the cyclic process shown in the figure. 
The American Journal of Applied sciences

(ISSN - 2689-0992)

VOLUME 04 ISSUE 01 Pages: 4-11

SJIF IMPACT FACTOR (2020: 5. 276) (2021: 5. 634)

OCLC - 1121105553 METADATA IF -7.987

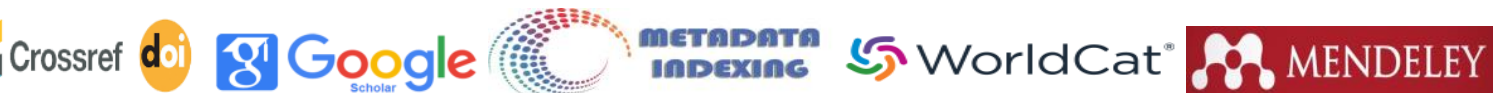

Publisher: The USA Journals
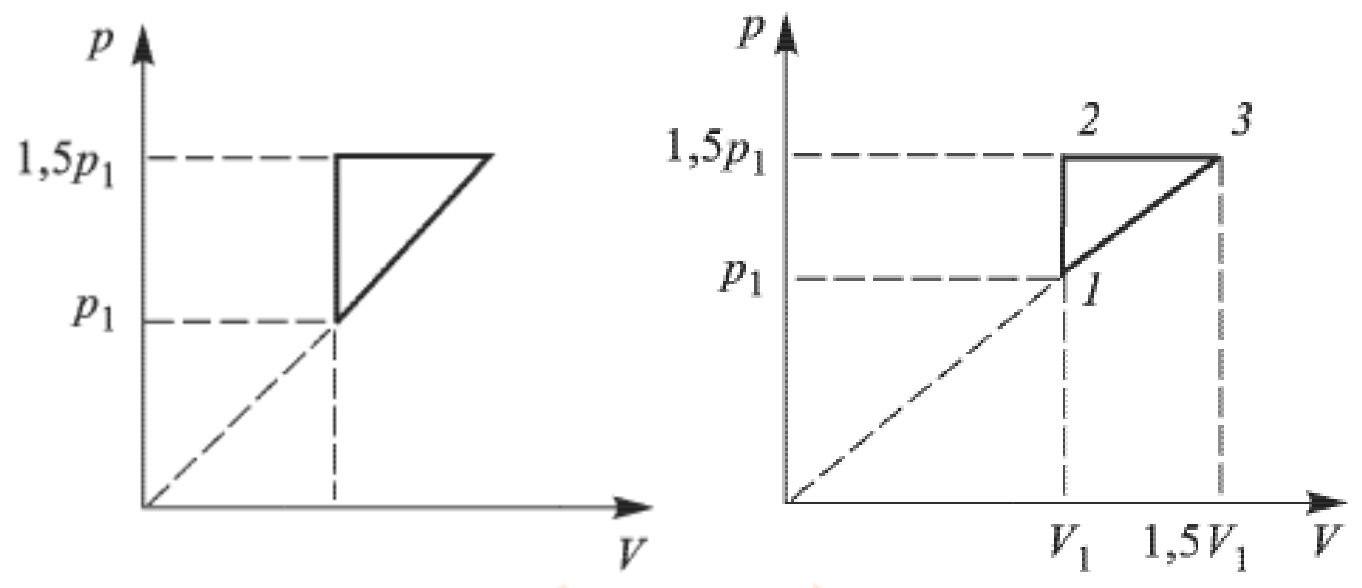

Solution:

The gas density values at points 1, 2 and 3 (see figure) are equal to:

$\rho_{1}=\frac{p_{1} M}{R T_{1}}, \quad \rho_{2}=\frac{p_{2} M}{R T_{2}}, \quad \rho_{3}=\frac{p_{2} M}{R T_{3}}$,

where $M$-molargasmass, $T_{1}, T_{2}$ and $T_{3}$ _ gas temperature at these points. Since the volume of gas at points 1 and 2 is the same, $p_{1} / T_{1}=p_{2} / T_{2}$. Hence, $\rho_{2}=\rho_{1}$ т.e. those. in section 1-2, the gas density does not change. In section 2-3, passing at constant pressure $V_{1} / T_{2}=V_{3} / T_{3}$, whence it follows that, $T_{3}=1,5 T_{2}$ . So $\rho_{3}=\frac{1}{1,5} \rho_{1}$.

$$
k=\frac{\rho_{1}}{\rho_{3}}=1,5
$$

Problem 3. With an ideal monatomic gas, process $1-2$ is carried out, shown in the figure. How many times will the average kinetic energy of a gas molecule change in this case? 
The American Journal of Applied sciences

(ISSN - 2689-0992)

VOLUME 04 ISSUE 01 Pages: 4-11

SJIF IMPACT FACTOR (2020: 5. 276) (2021: 5. 634)

OCLC - 1121105553 METADATA IF -7.987

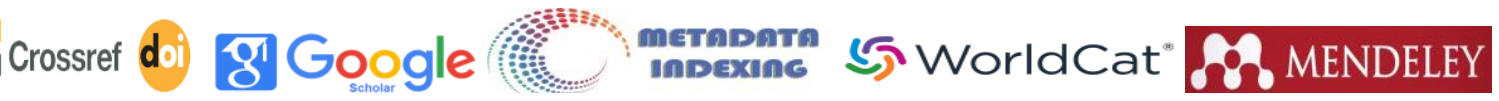

Publisher: The USA Journals

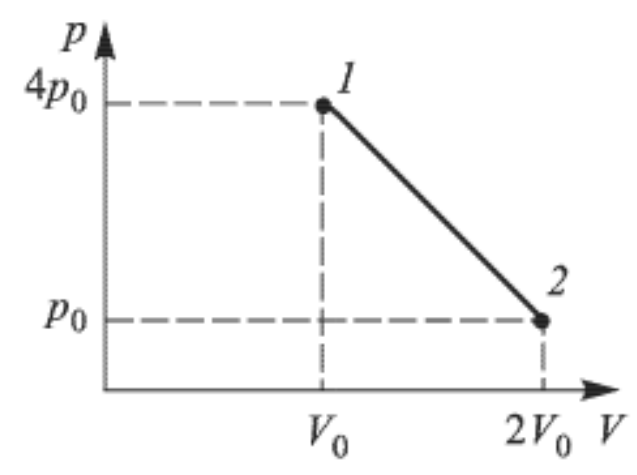

Solution:

Since the average kinetic energy of a monatomic gas molecule

$\overline{E_{\mathrm{K}}}=\frac{3}{2} k T$,

the desired energy ratio is equal to the ratio of the absolute temperatures of the gas in states 2 and 1 , i.e $\quad \alpha=T_{2} / T_{1}$.Writing the Clapeyron-Mendeleev equation for these states, we have: $V_{0} \cdot 4 p_{0}=\nu R T_{1}, \quad 2 V_{0} \cdot p_{0}=\nu R T_{2}$,

where $\nu$ - moles of gas, $R$ - universal gas constant. From here it is clear that $T_{2} / T_{1}=1 / 2$. Hence, $\alpha=\frac{1}{2}$, those. the average kinetic energy of a gas molecule in process $1-2$ will decrease by a factor of 2 .

Problem 4. A horizontal gas cylinder is divided into three chambers by two fixed pistons. The gas temperature in all chambers is the same and equal to $T_{1}$. Gas pressure in the first chamber $p_{1}$, volume $V_{1}$, in the second $p_{2}, V_{2}$, in the third respectively $p_{3}, V_{3}$. What will be the pressure $p$, in the chambers after releasing the pistons, allow them to move freely, and make the gas temperature equal to $T_{2}$ ?

Solution:

Let us write the equations of state for gas portions in the chambers: $p_{1} V_{1}=\nu_{1} R T_{1}, \quad p_{2} V_{2}=\nu_{2} R T_{1}, \quad p_{3} V_{3}=\nu_{3} R T_{1}$. 
The American Journal of Applied sciences

(ISSN - 2689-0992)

VOLUME 04 ISSUE 01 Pages: 4-11

SJIF IMPACT FACTOR (2020: 5. 276) (2021: 5. 634)

OCLC -1121105553 METADATA IF -7.987

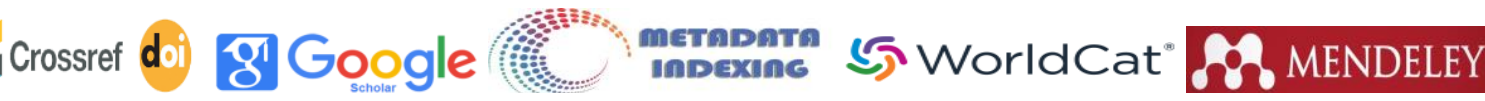

Publisher: The USA Journals

From here we find the amount of gas in each chamber

$\nu_{1}=\frac{p_{1} V_{1}}{R T_{1}}, \quad \nu_{2}=\frac{p_{2} V_{2}}{R T_{1}}, \quad \nu_{1}=\frac{p_{3} V_{3}}{R T_{1}}$

When the pistons are released, the pressure in all chambers will become the same and the equation of state of the gas will take the form:

$p\left(V_{1}+V_{2}+V_{3}\right)=\left(\nu_{1}+\nu_{2}+\nu_{3}\right) R T_{2}$

Substituting here the above found quantities of gas, we get the answer:

$$
p=\frac{\left(p_{1} V_{1}+p_{2} V_{2}+p_{3} V_{3}\right) T_{2}}{\left(V_{1}+V_{2}+V_{3}\right) T_{1}} .
$$

Problem 5. A bottle containing $m_{1}=1 \mathrm{~K} \Gamma$ nitrogen, when tested for strength exploded at a temperature $t_{1}=327^{\circ} \mathrm{C}$. What mass $m_{2}$ of hydrogen could be stored in such a cylinder at a temperature $t_{2}=27^{\circ} \mathrm{C}$, having a fivefold margin of safety? Molar mass of nitrogen $M_{1}=28$ г/моль, Molar mass of hydrogen $M_{2}=2$ г/моль.

Solution:

From the equation of state of nitrogen it follows that the pressure at which the balloon exploded $p_{1}=\frac{m_{1}}{M_{1}} \frac{R T_{1}}{V}$, where $V$ - baloon volume. According to the condition, hydrogen can be stored at a pressure $p_{2}=p_{1} / 5$. Considering, 
The American Journal of Applied sciences

(ISSN - 2689-0992)

VOLUME 04 ISSUE 01 Pages: 4-11

SJIF IMPACT FACTOR (2020: 5. 276) (2021: 5. 634)

OCLC - 1121105553 METADATA IF -7.987

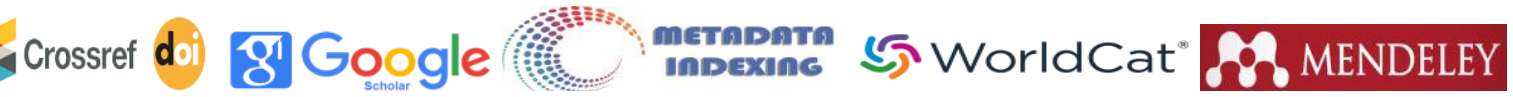

Publisher: The USA Journals

$p_{2}=\frac{m_{2}}{M_{2}} \frac{R T_{2}}{V}$, We get the answer: $m_{2}=\frac{m_{1}}{5} \frac{M_{2}}{M_{1}} \frac{t_{1}+273^{\circ} \mathrm{C}}{t_{2}+273^{\circ} \mathrm{C}} \approx 28 \Gamma$.

\section{CONCLUSION}

Therefore, for students to develop the ability to solve physical problems is the "Methodology for solving problems", which is compiled in such a way that it can be used for independent work. All material is divided into several stages. The analysis of the tasks is carried out according to a single scheme, and each chapter can be worked out independently of the others.

\section{REFERENCES}

1. Л.В.Голиш, А.М.Файзуллаева «Педагогик технологияларни лойихалаштириш ва режалаштириш». Т. 2010 й, 149-б.

2. A.N. Remizov "Tibbiy va biologik fizika" "O'zbekiston milliy ensiklopediyasi" Davlat ilmiy nashriyoti T. 2005 y, 592-b

3. ИшмухамедоваР.Ж. Инновацион технологиялар ёрдамида таълим самарадорлигини ошириш йўллари. Т: ТДПУ, 2004. - 446.

4. M.F. Atoyeva. Use of Periodicity in Teaching Physics. Eastern European Scientific Journal. - DüsseldorfGermany, 2017. № 4. -P. 35-39.

5. M.F. Atoyeva. Didactic foundations of inter-media relations in the training of university students. International Scientific Journal. Theoretical \& Applied Science. p-ISSN: 2308-4944 (print) e-ISSN: 2409-0085 (online). Year: 2020 Issue: 06 Volume: 86, Р. 124.

6. Заир-Бек С.И., Муштавинская И.В.Развитие критического мышления на уроке: Пособие для учителя. - М.: Просвещение, 2004. - 175 с.

7. M.F. Atoyeva. Pedagogical Tests As An Element Of Types Of Pedagogical Technologies. The American Journal of Applied Sciences, 2(09), (TAJAS) SJIF5.276 DOI-10.37547/tajas Volume 2 Issue 9, 19.09.2020. ISSN 2689-09. 92 The USA Journals, USA www.usajournalshub.com/index.php/tajas 164-169. Имп.5.2.

8. M.F. Atoyeva. The significance of periodicity at teaching physics. The Way of Science. - Volgograd, 2016. - № 10 (32). - P.62-64.

9. Атоева М.Ф. Эффективность обучения электродинамике на основе технологии периодичности. The Way of Science. - Volgograd, 2016. - № 10 (32). - P.65-66.

10. Zaripova Rano Ibodulloevna, Фразеологизмлар шаклланишига диалектизм, варваризм ва вульгаризмлар таъсири. Scientific - Methodical Journal of "Scientific Progress" .Volume \#2 Issue \#4, August 2021, P. 502-506. ISSN: 2181-1601. www.scientificprogress.uz.

11. Zaripova Rano Ibodulloevna, "Analysis Of The Protagonists Of The Novel Of The "Days Gone By"”. The American Journal Of Social Science And Education Innovations. 304 S. Jones Blvd \#5245 Las Vegas, NV 89107 USA. February, 2021.- Volume \# 3, Issue \#2. SJIF 2021: 5.857. www.usajournalshub.com/index.php/tajssei.

12. Zaripova Rano Ibodulloevna, Relation of Simple Phraseology in the English and Uzbek Languages to the Literary Language Norms. International Journal on Integrated Education. Impact Factor: SJIF2020=5.476. Vol. 3. -Issue III.- March 2020. P.9-16. e-ISSN: 2620-3502 p-ISSN: 2615- 3785. email: info@researchparks.org. http://journals.researchparks.org/

13. Zaripova Rano Ibodulloevna, Stages of the Stylistic Movement of Phraseological Units. International Journal on Integrated Education. Impact Factor: SJIF 2019=5.083. Vol. 2. -Issue I.- March 2019. - P. 56-61. e-ISSN: 2620-3502 p-ISSN: 2615-3785. e-mail: info@researchparks.org.

http://journals.researchparks.org/.

14. Atoeva Mehriniso Farhodovna, Arabov Jasur Olimboevich, Kobilov Bakhtiyor Badriddinovich. 
The American Journal of Applied sciences

(ISSN - 2689-0992)

VOLUME 04 ISSUE 01 Pages: 4-11

SJIF IMPACT FACTOR (2020: 5. 276) (2021: 5. 634)

OCLC - 1121105553 METADATA IF -7.987

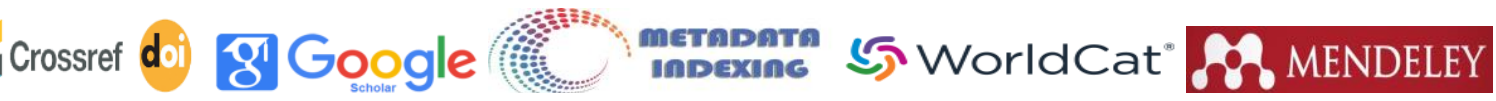

Technologies. The American Journal of Applied Sciences, 2(09), 164-169.

17. Asadovna, F. K. (2020). Modern pedagogical technologies of teaching physics in secondary school. European Journal of Research and Reflection in Educational Sciences, 8(12), Part III, 8590.

18. S. O. Saidov, M. F.Atoeva, Kh. A.Fayzieva, N.G.Nasirova, Z. Kh.Fayzieva. SOME Actual issues of teaching modern physics in higher education. psychology and education (2021) 58(1): (3542-3549 b). ISSN: 00333077. Yuldosheva Nilufar Bakhtiyorovna (2020). The Elements of Organization Of The Educational Process On The Basis of New Pedagogical

16. Saidov Safo Olimovich, Atoeva Mexriniso Farkhodovna, Fayzieva Kholida Asadovna,

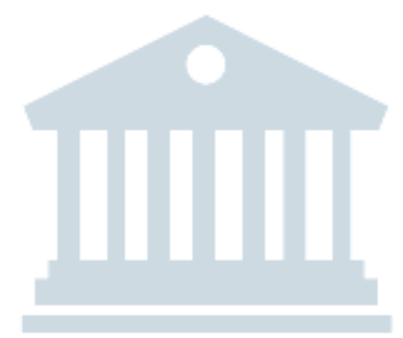

